\title{
Synthesis, Crystal Structure, and Thermal Decomposition of the Cobalt(II) Complex with 2-Picolinic Acid
}

\author{
Di Li and Guo-Qing Zhong \\ State Key Laboratory Cultivation Base for Nonmetal Composite and Functional Materials, \\ School of Material Science and Engineering, Southwest University of Science and Technology, Mianyang 621010, China
}

Correspondence should be addressed to Guo-Qing Zhong; zgq316@163.com

Received 28 August 2013; Accepted 20 October 2013; Published 20 January 2014

Academic Editors: Y. Frapart and Z. Hassani

Copyright (C) 2014 D. Li and G.-Q. Zhong. This is an open access article distributed under the Creative Commons Attribution License, which permits unrestricted use, distribution, and reproduction in any medium, provided the original work is properly cited.

\begin{abstract}
The cobalt(II) complex of 2-picolinic acid (Hpic), namely, $\left[\mathrm{Co}(\text { pic })_{2}\left(\mathrm{H}_{2} \mathrm{O}\right)_{2}\right] \cdot 2 \mathrm{H}_{2} \mathrm{O}$, was synthesized with the reaction of cobalt acetate and 2-picolinic acid as the reactants by solid-solid reaction at room temperature. The composition and structure of the complex were characterized by elemental analysis, infrared spectroscopy, single crystal X-ray diffraction, and thermogravimetrydifferential scanning calorimetry (TG-DSC). The crystal structure of the complex belongs to monoclinic system and space group $P 2(1) / n$, with cell parameters of $a=9.8468(7) \AA, b=5.2013(4) \AA, c=14.6041(15) \AA, \beta=111.745(6)^{\circ}, V=747.96(11) \AA^{3}, Z=2$, $D_{c}=1.666 \mathrm{~g} \mathrm{~cm}^{-3}, R_{1}=0.0297$, and $w R_{2}=0.0831$. In the title complex, the Co(II) ion is six-coordinated by two pyridine $\mathrm{N}$ atoms and two carboxyl $\mathrm{O}$ atoms from two 2-picolinic acid anions, and two $\mathrm{O}$ atoms from two $\mathrm{H}_{2} \mathrm{O}$ molecules, and forming a slightly distorted octahedral geometry. The thermal decomposition processes of the complex under nitrogen include dehydration and pyrolysis of the ligand, and the final residue is cobalt oxalate at about $450^{\circ} \mathrm{C}$.
\end{abstract}

\section{Introduction}

In recent years, chemists have tended to design and synthesise metal-organic frameworks, which are undergoing accelerated and sustained growth because of their fascinating structures and potential applications, such as molecular adsorption, catalysis, gas storage, multifunctional materials, and chemical separation [1-10]. The transition metal carboxylates have the diversity of coordination modes for carboxyl group, which tend to form cluster or polymer structures [11], and it is significance to synthesis of some specific structure and function complexes in future. It is known that 2-picolinic acid is terminal tryptophan metabolite, and its anion has been used as a valuable chelating ligand, and the pyridine $\mathrm{N}$ atom and the carboxylate oxygen atoms are capable of coordinating various metal ions. Besides, 2-picolinic acid is not only a potential proton acceptor but also proton donor depending on deprotonated groups [12]. To the best of our knowledge, the crystal structures of 2-picolinic acid with $\mathrm{Ni}(\mathrm{II}), \mathrm{Zn}(\mathrm{II})$, $\mathrm{Co}(\mathrm{III})$, and $\mathrm{Cu}$ (II) derivations have been reported [11-14].

The method of room temperature solid-solid synthesis is a simple and convenient method for the preparation of metal complexes, and many complexes have been synthesized by this method [15-17]. Advantages of the solid-solid synthesis method are much higher yield, being inexpensive, faster reaction rate, easier operating, energy saving, and environmental friendly [18], and it is in accordance with the requirements of green chemistry. Cobalt is an essential trace element for human and all animals, and its complexes have been used in the fields of medicine, bioinorganic chemistry, functional materials, and so forth [19-24]. At the same time, the cobalt compounds are often used in chemical reactions as oxidation catalysts, such as typical catalysts that are the cobalt carboxylates, which are also used in paints, varnishes, and pigments industry [25]. We report herein the X-ray single crystal structure and thermal property of the cobalt(II) complex of 2-picolinic acid which is synthesized by solidsolid reaction at room temperature.

\section{Experimental}

2.1. Materials and Physical Measurements. All the chemicals used in the experiments were analytical reagents as received 
TABLE 1: Crystal data and structure refinement parameters for the title complex.

\begin{tabular}{lccc}
\hline Empirical formula & $\mathrm{CoC}_{12} \mathrm{H}_{16} \mathrm{O}_{8} \mathrm{~N}_{2}$ & $F(000)$ & 386 \\
Formula weight & $375.20 \mathrm{~g} \mathrm{~mol}^{-1}$ & Crystal size & $0.42 \mathrm{~mm} \times 0.35 \mathrm{~mm} \times 0.25 \mathrm{~mm}$ \\
Temperature & $298(2) \mathrm{K}$ & Theta range for data collection & $2.50-25.02^{\circ}$ \\
Wavelength & $0.71073 \AA$ & Limiting indices & $-11 \leq h \leq 8,-6 \leq k \leq 6,-15 \leq l \leq 17$ \\
Crystal system & Monoclinic & Reflections collected/unique & $3424 / 1320[R(\mathrm{int})=0.0438]$ \\
Space group & $P 2(1) / n$ & Completeness to theta $=25.02$ & $99.6 \%$ \\
Unit cell dimensions & & Absorption correction & Semiempirical from equivalents \\
$a$ & $9.8468(7) \AA$ & Max. and min. transmission & 0.7549 and 0.6344 \\
$b$ & $5.2013(4) \AA$ & Refinement method & Full-matrix least squares on $F^{2}$ \\
$c$ & $14.6041(15) \AA$ & Data/restraints/parameters & $1320 / 0 / 107$ \\
$\beta$ & $90.2310(10)^{\circ}$ & Goodness of fit on $F^{2}$ & 1.077 \\
Volume & $747.96(11) \AA^{3}$ & Final $R$ indices $[I>2 \sigma(I)]$ & $R_{1}=0.0297, w R_{2}=0.0831$ \\
$Z$ & 2 & $R$ indices (all data) & $R_{1}=0.0338, w R_{2}=0.0877$ \\
Calculated density & $1.666 \mathrm{~g} \mathrm{~cm}^{-3}$ & Extinction coefficient & $0.222(10)$ \\
Absorption coefficient & $1.192 \mathrm{~mm}^{-1}$ & Largest diff. peak and hole & 0.333 and $-0.358 \mathrm{e} \AA^{-3}$ \\
\hline
\end{tabular}

from commercial sources and without further purification. 2Picolinic acid was purchased from Alfa Aesar, while cobalt(II) acetate tetrahydrate was purchased from Merck.

The contents of carbon, hydrogen, and nitrogen in the complex were measured by a Vario EL CUBE elemental analyzer, and the cobalt content was determined by EDTA complexometric titration. The FTIR spectra were obtained with a Perkin-Elmer Spectrum One-Spectrometer in the ranges of $400-4000 \mathrm{~cm}^{-1}$ using $\mathrm{KBr}$ pellets. The thermogravimetric analysis of the metal complex was performed by a SDT Q600 thermogravimetric analyzer, and the measurement was recorded from 30 to $600^{\circ} \mathrm{C}$ at the heating rate of $10^{\circ} \mathrm{C} \mathrm{min}^{-1}$ under nitrogen flow of $50 \mathrm{~mL} \mathrm{~min}^{-1}$. X-ray powder diffraction was performed using a D/max-II X-ray diffractometer, $\mathrm{Cu} K_{\alpha}$ radiation $(\lambda=0.154056 \mathrm{~nm}$, step width: $2 \theta=0.2^{\circ}$, and scan speed: $\left.8^{\circ} / \mathrm{min}\right)$.

2.2. Synthesis of the Complex $\left[\mathrm{Co}(\text { pic })_{2}\left(\mathrm{H}_{2} \mathrm{O}\right)_{2}\right] \cdot 2 \mathrm{H}_{2} \mathrm{O}$. The synthesis reaction of the title complex is as follows:

$$
\begin{aligned}
2 \mathrm{C}_{6} \mathrm{H}_{5} \mathrm{O}_{2} \mathrm{~N} & +\mathrm{Co}\left(\mathrm{CH}_{3} \mathrm{COO}\right)_{2} \cdot 4 \mathrm{H}_{2} \mathrm{O} \\
\longrightarrow & {\left[\mathrm{Co}\left(\mathrm{C}_{6} \mathrm{H}_{4} \mathrm{O}_{2} \mathrm{~N}\right)_{2}\left(\mathrm{H}_{2} \mathrm{O}\right)_{2}\right] \cdot 2 \mathrm{H}_{2} \mathrm{O} } \\
& +2 \mathrm{CH}_{3} \mathrm{COOH} \uparrow
\end{aligned}
$$

2-Picolinic acid and cobalt acetate of the two reactants were weighed and placed in an agate mortar, and the molar ratio of 2 -picolinic acid to cobalt acetate was $2: 1$. Then, the mixture was grinded carefully at room temperature and released a strong irritant gas in the grinding process. The released gas was tested with moist $\mathrm{pH}$ paper, and the result indicated that the gas was faintly acid gas. The reason was that the acetic acid was released in the reaction process. When there was no irritant gas that escaped, the reaction was completed. The reaction was conducted in grinding at room temperature for $6 \mathrm{~h}$, and the mixture became into loose pink powder. Afterwards the resultant was transferred to the beaker and stirred to dissolve with a little distilled water, and the solution was filtered and concentrated. The concentrated solution was placed at room temperature about 10 days, and the red-orange crystals of the cobalt(II) complex were obtained. The yield of the complex was about $82 \%$. Anal. Calcd. for $\mathrm{CoC}_{12} \mathrm{H}_{16} \mathrm{O}_{8} \mathrm{~N}_{2}$ (\%): C, 38.40; H, 4.27; N, 7.47; Co, 15.71. Found (\%): C, 38.26; H, 4.23; N, 7.41; Co, 15.53 .

2.3. X-Ray Diffraction Crystallography. The appropriate crystal was cut from larger crystals and mounted on a Bruker Smart Apex II CCD diffractometer with graphite monochromated Mo $K_{\alpha}$ radiation $(\lambda=0.71073 \AA)$. The data were collected at 298(2) $K$ using multiscan modes. A red-orange crystal with dimensions $0.42 \mathrm{~mm} \times 0.35 \mathrm{~mm} \times 0.25 \mathrm{~mm}$ was mounted on a glass fiber. Diffraction data were collected in $\omega$ mode in the ranges of $2.50^{\circ}-25.02^{\circ}$. The programs SHELXS-97 and SHELXL-97 were used for the structure determination and refinement $[26,27]$. The structure was solved by direct methods, and all nonhydrogen atoms were obtained from the difference Fourier map and subjected to anisotropic refinement by full-matrix least squares on $F^{2}$. All nonhydrogen atoms were refined anisotropically. The structure refinement parameters for the title complex are given in Table 1, and the crystallographic data are deposited with the Cambridge Crystallographic Data Centre under deposition number CCDC 913361.

\section{Results and Discussion}

3.1. X-Ray Crystal Structure Analysis. Figure 1 shows the key fragments of the structures and the atom numbering in the title complex. Crystallographic data and structure refinement parameters for the title complex are given in Table 1, and the selected bond distances and angles are shown in Table 2. The unit of the complex is composed of one $\mathrm{Co}$ (II) ion, two 2picolinic acid anions, and four water molecules. The Co(II) ion occupies the center of symmetry, which is six-coordinated through two nitrogen atoms and two hydroxy oxygen atoms 
TABLE 2: Selected bond lengths $(\AA)$ and angles $\left({ }^{\circ}\right)$ for the title complex.

\begin{tabular}{lccc}
\hline $\mathrm{Co}(1)-\mathrm{O}(1) \# 1$ & $2.0765(15)$ & $\mathrm{Co}(1)-\mathrm{O}(1)$ & $2.0765(15)$ \\
$\mathrm{Co}(1)-\mathrm{N}(1) \# 1$ & $2.1196(18)$ & $\mathrm{Co}(1)-\mathrm{N}(1)$ & $2.1196(18)$ \\
$\mathrm{Co}(1)-\mathrm{O}(3) \# 1$ & $2.1477(16)$ & $\mathrm{Co}(1)-\mathrm{O}(3)$ & $2.1477(16)$ \\
$\mathrm{N}(1)-\mathrm{C}(6)$ & $1.339(3)$ & $\mathrm{N}(1)-\mathrm{C}(2)$ & $1.344(3)$ \\
$\mathrm{O}(1)-\mathrm{C}(1)$ & $1.277(3)$ & $\mathrm{O}(2)-\mathrm{C}(1)$ & $1.242(3)$ \\
$\mathrm{O}(1) \# 1-\mathrm{Co}(1)-\mathrm{O}(1)$ & $180.00(8)$ & $\mathrm{O}(1) \# 1-\mathrm{Co}(1)-\mathrm{N}(1) \# 1$ & $78.92(7)$ \\
$\mathrm{O}(1)-\mathrm{Co}(1)-\mathrm{N}(1) \# 1$ & $101.08(7)$ & $\mathrm{O}(1) \# 1-\mathrm{Co}(1)-\mathrm{N}(1)$ & $101.08(7)$ \\
$\mathrm{O}(1)-\mathrm{Co}(1)-\mathrm{N}(1)$ & $78.92(7)$ & $\mathrm{N}(1) \# 1-\mathrm{Co}(1)-\mathrm{N}(1)$ & 180.0 \\
$\mathrm{O}(1) \# 1-\mathrm{Co}(1)-\mathrm{O}(3) \# 1$ & $90.89(6)$ & $\mathrm{N}(1)-\mathrm{Co}(1)-\mathrm{O}(3) \# 1$ & $89.11(6)$ \\
$\mathrm{N}(1) \# 1-\mathrm{Co}(1)-\mathrm{O}(3) \# 1$ & $84.49(7)$ & $\mathrm{O}(1)-\mathrm{Co}(1)-\mathrm{O}(3)$ & $95.51(7)$ \\
$\mathrm{O}(1) \# 1-\mathrm{Co}(1)-\mathrm{O}(3)$ & $89.11(6)$ & $\mathrm{N}(1)-\mathrm{Co}(1)-\mathrm{O}(3)$ & $90.89(6)$ \\
$\mathrm{N}(1) \# 1-\mathrm{Co}(1)-\mathrm{O}(3)$ & $95.51(7)$ & $\mathrm{C}(2)-\mathrm{N}(1)-\mathrm{Co}(1)$ & $84.49(7)$ \\
$\mathrm{O}(3) \# 1-\mathrm{Co}(1)-\mathrm{O}(3)$ & 180.0 & $\mathrm{O}(1)-\mathrm{C}(1)-\mathrm{C}(2)$ & $112.10(15)$ \\
$\mathrm{C}(1)-\mathrm{O}(1)-\mathrm{Co}(1)$ & $116.23(14)$ & $\mathrm{O}(2)-\mathrm{C}(1)-\mathrm{O}(1)$ & $116.10(19)$ \\
$\mathrm{N}(1)-\mathrm{C}(2)-\mathrm{C}(1)$ & $116.00(18)$ & & $124.8(2)$ \\
$\mathrm{O}(2)-\mathrm{C}(1)-\mathrm{C}(2)$ & $119.1(2)$ & & \\
\hline
\end{tabular}

Symmetry transformations used to generate equivalent atoms: $\# 1-x+1,-y+1,-z+1$.

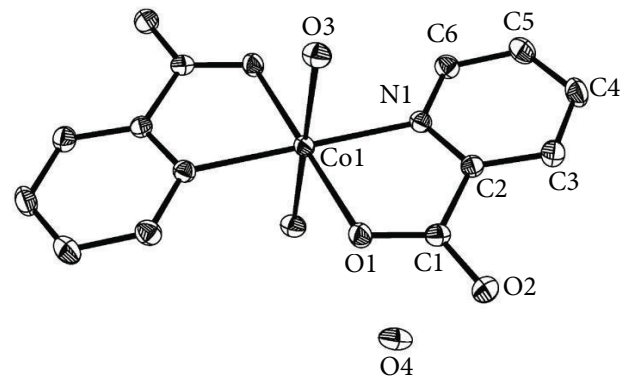

Figure 1: Molecular structure of the title complex.

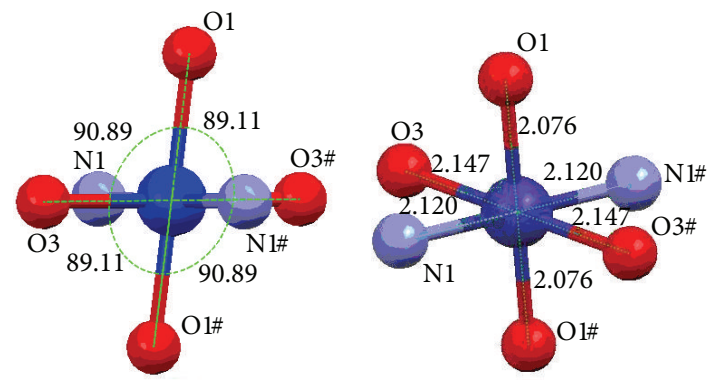

FIGURE 2: Coordination environment of the Co(II) ion.

of the carboxyl group [Co(1)-N(1), 2.1196(18) $\AA$; $\mathrm{Co}(1)-$ $\mathrm{N}(1) \# 1,2.1196(18) \AA$; and $\mathrm{Co}(1)-\mathrm{O}(1), 2.0765(15) \AA$; $\mathrm{Co}(1)-$ $\mathrm{O}(1) \# 1,2.0765(15) \AA]$ from two 2-picolinic acid anions and two oxygen atoms from two $\mathrm{H}_{2} \mathrm{O}$ molecules $[\mathrm{Co}(1)-\mathrm{O}(3)$, 2.1477(16) $\AA$; and $\mathrm{Co}(1)-\mathrm{O}(3) \# 1,2.1477(16) \AA]$. The complex is formed by 2-picolinic acid anion as bidentate ligand and the space group is $P 2(1) / n$. The $\mathrm{O}$ or $\mathrm{N}$ atoms of coordination from the two 2-picolinic acid molecules are equivalent. Figure 2 shows that the four atoms of $\mathrm{O}(1), \mathrm{N}(1)$, $\mathrm{O}(1) \# 1$, and $\mathrm{N}(1) \# 1$ are in the equatorial plane and form

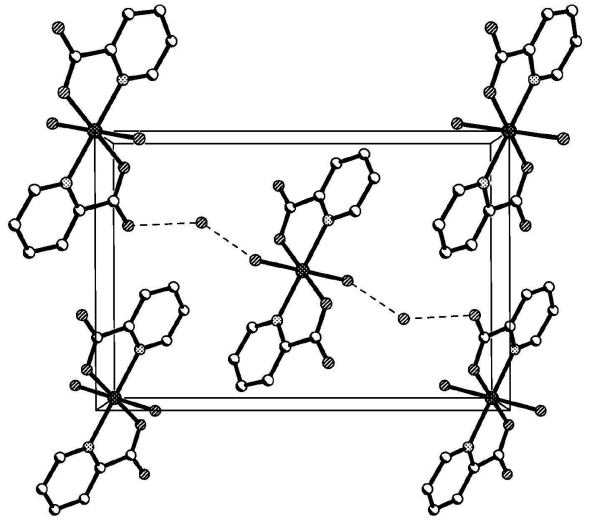

FIgURE 3: Crystal packing diagram of the title complex.

a parallelogram array, and the bond angle of $\mathrm{O}(3) \# 1-\mathrm{Co}(1)-$ $\mathrm{O}(3)$ is $180^{\circ}$ and the atoms of $\mathrm{O}(3) \# 1, \mathrm{Co}(1)$, and $\mathrm{O}(3)$ are in a straight line; therefore the two atoms of $\mathrm{O}(3)$ and $\mathrm{O}(3) \# 1$ from the coordinated water molecules are in the axial symmetry position, forming a slightly distorted octahedral geometry. In the complex, the bond length of $\mathrm{Co}(1)-\mathrm{O}(1)$ is slightly shorter than the bond lengths of $\mathrm{Co}(1)-\mathrm{N}(1)$ and $\mathrm{Co}(1)-\mathrm{O}(3)$; this indicates that the coordination ability of the carboxyl $\mathrm{O}$ atom is stronger than that of the $\mathrm{N}$ atom from pyridine ring and the $\mathrm{O}$ atom from water molecule. The bond angles $(\mathrm{O}(1)-\mathrm{Co}(1)-$ $\mathrm{O}(3)$ and $\mathrm{O}(1) \# 1-\mathrm{Co}(1)-\mathrm{O}(3) \# 1,90.89(6)^{\circ}$; $\mathrm{O}(1) \# 1-\mathrm{Co}(1)-$ $\mathrm{O}(3)$ and $\left.\mathrm{O}(1)-\mathrm{Co}(1)-\mathrm{O}(3) \# 1,89.11(6)^{\circ}\right)$ in the complex are near to ideal $90^{\circ}$ values. Because of the Jahn-Teller effect of the $\mathrm{Co}(\mathrm{II})$ ion with $\mathrm{d}^{7}$ electron configuration, the axial bond lengths of $\mathrm{Co}(1)-\mathrm{O}(3)$ and $\mathrm{Co}(1)-\mathrm{O}(3) \# 1$ are stretched.

In Figures 3 and 4, the molecules of the complex $\left[\mathrm{Co}(\mathrm{pic})_{2}\left(\mathrm{H}_{2} \mathrm{O}\right)_{2}\right] \cdot 2 \mathrm{H}_{2} \mathrm{O}$ are held together by intermolecular hydrogen bonds. Hydrogen bond length and bond angle for the title complex are given in Table 3. There are three 
TABLE 3: Hydrogen bond lengths $(\AA)$ and bond angles $\left({ }^{\circ}\right)$ for the title complex.

\begin{tabular}{lccccc}
\hline D-H & $d(\mathrm{D}-\mathrm{H})$ & $d(\mathrm{H} \cdots \mathrm{A})$ & LDHA & $d(\mathrm{D} \cdots \mathrm{A})$ & $\mathrm{A}$ \\
\hline O3-H3C & 0.850 & 1.896 & 171.34 & 2.739 & $\mathrm{O} 1[-x+1,-y,-z+1]$ \\
O3-H3D & 0.851 & 1.963 & 171.40 & 2.808 & $\mathrm{O} 4[x-1 / 2,-y+3 / 2, z+1 / 2]$ \\
O4-H4C & 0.850 & 1.852 & 175.51 & 2.700 & $\mathrm{O} 2[x, y+1, z]$ \\
O4-H4D_a & 0.850 & 2.095 & 175.29 & 2.943 & $\mathrm{O} 4[-x+3 / 2, y-1 / 2,-z+1 / 2]$ \\
O4-H4B_b & 0.849 & 2.203 & 145.57 & 2.943 & $\mathrm{O} 4[-x+3 / 2, y+1 / 2,-z+1 / 2]$ \\
\hline
\end{tabular}

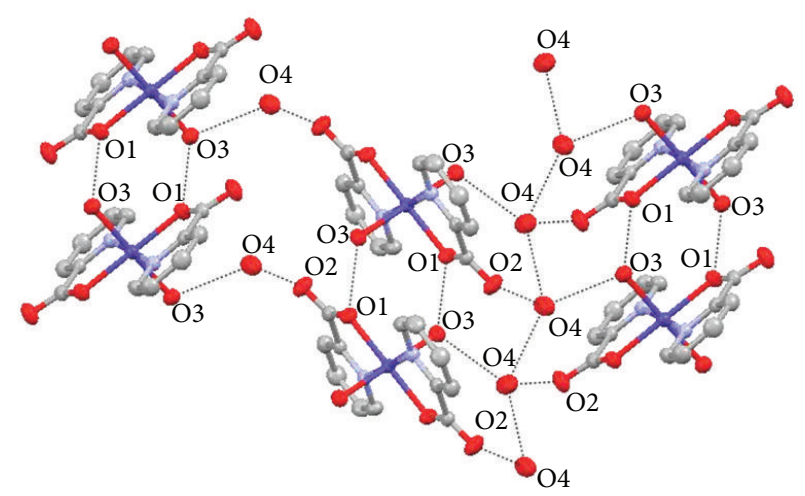

FIGURE 4: Packing diagram of the title complex showing $\mathrm{H}$ bonding.

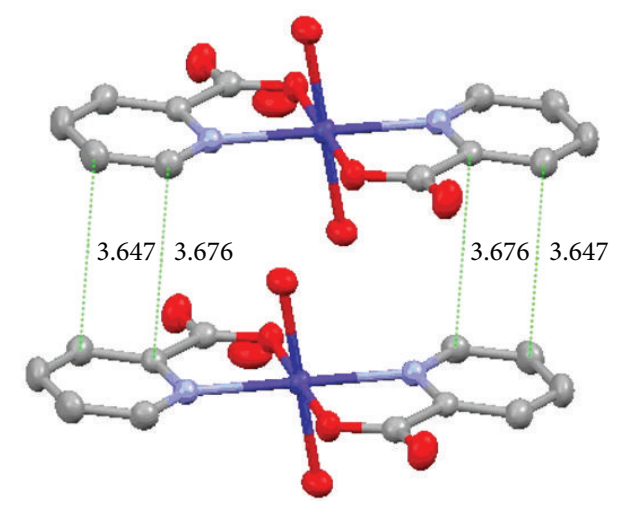

FIGURE 5: Weak spatial $\pi-\pi$ stacking interactions of the title complex.

types of hydrogen bonds in the crystal of the Co(II) complex, and they are the weak hydrogen bonds between the crystalline water molecules (O4-H4D .. O 4 and O4-H4B ‥ O4, $2.943 \AA$ ), the hydrogen bonds between the crystalline water and the coordinated water molecules $(\mathrm{O} 3-\mathrm{H} 3 \mathrm{D} \cdots \mathrm{O} 4$, $2.808 \AA$ ), and the strong hydrogen bonds between the oxygen atoms of the carboxylate groups with coordinated and crystallization water molecules (O3-H3C... O1, $2.739 \AA$; and O4-H4C... O1, $2.700 \AA$ ), respectively. Hydrogen bonds exist between the crystalline water and the coordinated water molecules, which form a 1D zigzag polymeric chain. At the same time the hydrogen bonds between the carboxyl oxygen atoms and the coordinated water molecules from the different complex molecules form 2D layers; as a result, these $2 \mathrm{D}$ layers are extended through extensive hydrogen bonding

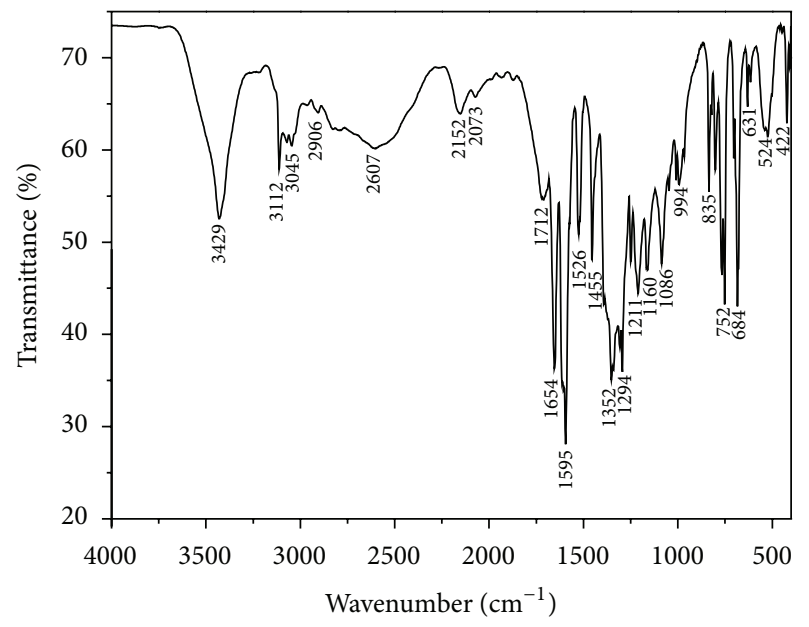

FIGURE 6: FT-IR spectra of the ligand 2-picolinic acid.

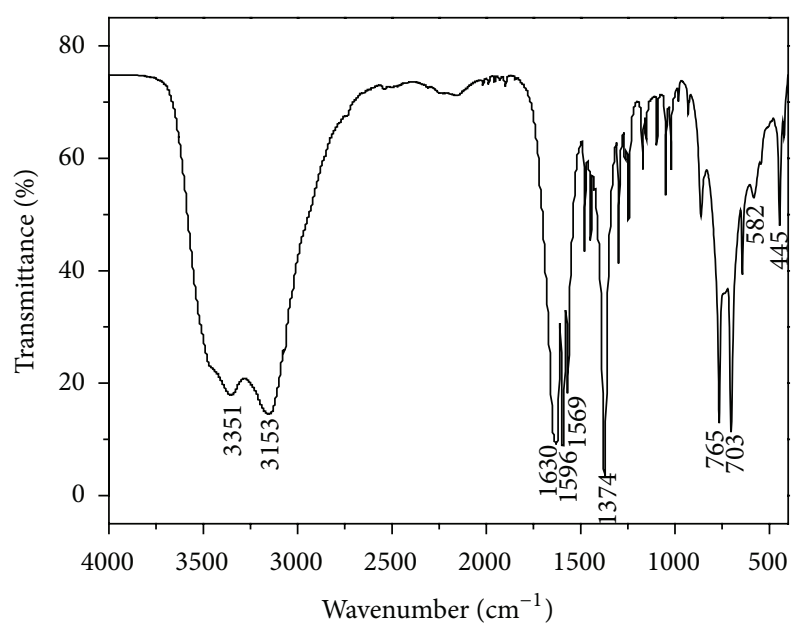

FIGURE 7: FT-IR spectra of the title complex.

interactions to form an infinite 3D supramolecular network, and make the molecular structure more stable. Besides, the distances between pyridine rings situating in neighbouring mirror planes are $3.647 \AA$ and $3.676 \AA$ in Figure 5, which may indicate the existence of face-to-face $\pi-\pi$ stacking weak interactions in the complex [28].

3.2. FT-IR Spectra. The FT-IR spectra of 2-picolinic acid and the title complex are given in Figures 6 and 7. Comparison of IR spectra of the free ligand reveals that considerable changes 
TABLE 4: Thermal decomposition data of the title complex.

\begin{tabular}{lccc}
\hline Reaction & DSC ${ }^{\circ} \mathrm{C}$ & $W_{\text {exp }}$ & Mass loss \% \\
\hline$\left[\mathrm{Co}\left(\mathrm{C}_{5} \mathrm{H}_{4} \mathrm{NCOO}\right)_{2}\left(\mathrm{H}_{2} \mathrm{O}\right)_{2}\right] \cdot 2 \mathrm{H}_{2} \mathrm{O}$ & 9.85 & $W_{\text {cal }}$ \\
$\downarrow-2 \mathrm{H}_{2} \mathrm{O}$ & 96 (endo.) & & 9.60 \\
{$\left[\mathrm{Co}\left(\mathrm{C}_{5} \mathrm{H}_{4} \mathrm{NCOO}\right)_{2}\left(\mathrm{H}_{2} \mathrm{O}\right)_{2}\right]$} & & & \\
$\downarrow-2 \mathrm{H}_{2} \mathrm{O}$ & 130 (endo.) & 9.45 & 9.60 \\
{$\left[\mathrm{Co}\left(\mathrm{C}_{5} \mathrm{H}_{4} \mathrm{NCOO}\right)_{2}\right]$} & & & \\
$\downarrow-\mathrm{C}_{5} \mathrm{H}_{4} \mathrm{~N}-\mathrm{C}_{5} \mathrm{H}_{4} \mathrm{~N}\left(2,2^{\prime}\right.$-bipy) & 401 (endo.) & 42.17 & 41.63 \\
$\mathrm{CoC}_{2} \mathrm{O}_{4}$ & & $38.53^{*}$ & $39.17^{* *}$ \\
\hline
\end{tabular}

${ }^{*}$ The experimental percentage mass of the residue in the sample.

***The calculated percentage mass of the residue in the sample.

in frequencies have occurred which can determine the coordination sites in chelation. A wide intense absorption band around $3351 \mathrm{~cm}^{-1}$ can be assigned to stretching vibration of hydroxyl from the water molecules. The bands corresponding to the stretching vibration of the $\mathrm{C}-\mathrm{H}$ and $\mathrm{C}=\mathrm{N}$ are situated at $3153 \mathrm{~cm}^{-1}$ and $1630 \mathrm{~cm}^{-1}$, respectively. The vibration peak found in the $1569 \mathrm{~cm}^{-1}$ region is assigned to the stretching vibration of the $\mathrm{C}=\mathrm{C}-\mathrm{C}=\mathrm{C}$ bond. The difference value of $222 \mathrm{~cm}^{-1}$ between the asymmetric $\left(1596 \mathrm{~cm}^{-1}\right)$ and symmetric $\left(1374 \mathrm{~cm}^{-1}\right)$ stretching vibration of the carboxylate group is in line with a monodentate type of coordination [2931]. The band corresponding to the stretching vibration of the $\mathrm{C}=\mathrm{O}$ group of the Hpic monomer is situated at 1700 $1769 \mathrm{~cm}^{-1}$ and disappears in the complex. The IR spectra of 2-picolinic acid contain broad absorption bands at $2607 \mathrm{~cm}^{-1}$ and $2152 \mathrm{~cm}^{-1}$ and indicate the existence of $\mathrm{O}-\mathrm{H} \cdots \mathrm{N}$ type of intermolecular hydrogen bonding, but it disappears in the complex whose phenomenon confirms that the nitrogen atom is coordinated to the cobalt ion. The absorption peaks at $765 \mathrm{~cm}^{-1}$ and $703 \mathrm{~cm}^{-1}$ for the complex are assigned to deformation vibration of the pyridine ring and compared with the absorption peaks at $752 \mathrm{~cm}^{-1}$ and $684 \mathrm{~cm}^{-1}$ from the 2-picolinic acid ligand, which confirms that the pyridyl $\mathrm{N}$ atom and carboxyl $\mathrm{O}$ atom are coordinated with the center cobalt ion. The absorption peak found in the $445 \mathrm{~cm}^{-1}$ region is assigned to the $\mathrm{Co}-\mathrm{N}$ bond and in the $422 \mathrm{~cm}^{-1}$ region is assigned to the $\mathrm{Co}-\mathrm{O}$ bond [32].

3.3. Thermal Analysis. To study the thermal decomposition process of complexes is helpful to the understanding of the coordination structure of the complexes $[33,34]$. The thermal stability of the title complex in nitrogen was investigated by TG-DSC analysis. The TG-DSC curves of the complex are shown in Figure 8, and the possible pyrolysis reaction and the experimental and calculated percentage mass losses in the thermal decomposition process of the complex are summarized in Table 4 . As Figure 8 shows, there are three endothermic peaks at $96^{\circ} \mathrm{C}, 130^{\circ} \mathrm{C}$, and $401^{\circ} \mathrm{C}$ in the DSC curve. The first mass loss of $\left[\mathrm{Co}(\mathrm{pic})_{2}\left(\mathrm{H}_{2} \mathrm{O}\right)_{2}\right] \cdot 2 \mathrm{H}_{2} \mathrm{O} \cdot 2 \mathrm{H}_{2} \mathrm{O}$ occurs at about $96^{\circ} \mathrm{C}$, corresponding to the release of two molecules of crystalline water. This is consistent with the single crystal structure. The experimental percentage mass

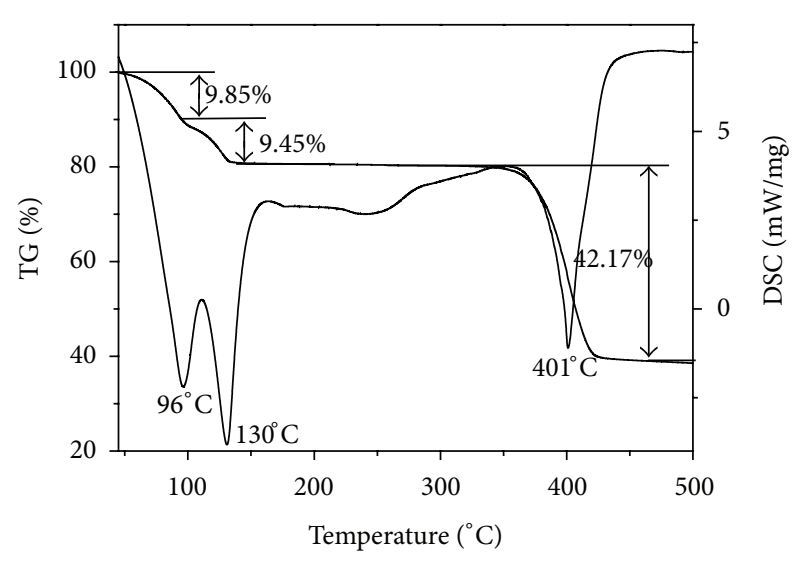

FIgURE 8: TG-DSC curves of the title complex.

loss $(9.85 \%)$ is close to the calculated one $(9.60 \%)$. The second mass loss of $9.45 \%$ (calcd. 9.60\%) occurs between 100 and $140^{\circ} \mathrm{C}$, which show loss of two water molecules from the complex. Because of the high dehydration temperature, this loss of the two water molecules should be coordinated water. After the four water molecules are lost, the complex become to be $\left[\mathrm{Co}(\mathrm{pic})_{2}\right]$. The residue complex of $\left[\mathrm{Co}(\mathrm{pic})_{2}\right]$ is relatively stable in nitrogen between 140 and $350^{\circ} \mathrm{C}$. The next step mass loss in the temperature ranges of 350 $450^{\circ} \mathrm{C}$ corresponds to the loss of two pyridine free radicals $\left(\cdot \mathrm{C}_{5} \mathrm{H}_{4} \mathrm{~N}\right)$, and the two free radicals may eventually form $2,2^{\prime}$-bipyridine and then escape to volatile. This is just why there is an appreciable endothermic peak at $401^{\circ} \mathrm{C}$ in the DSC curve. The mass loss of $42.17 \%$ in the TG curve is in good agreement with the calculated result of $41.63 \%$. The residual mass of the complex remains almost constant in nitrogen until $500^{\circ} \mathrm{C}$. The composition of the final residue is cobalt oxalate, and the experimental result $(39.17 \%)$ is in agreement with the result of theoretical calculation (38.53\%). The XRD pattern of the residue is shown in Figure 9, and the characteristic peaks of the residue are mostly consistent with the normative peaks according to the JCPDS cards number 25-0250 $\left(\mathrm{CoC}_{2} \mathrm{O}_{4}\right)$. The result of thermal analysis further ascertains that the molecule composition of the complex is $\left[\mathrm{Co}(\mathrm{pic})_{2}\left(\mathrm{H}_{2} \mathrm{O}\right)_{2}\right] \cdot 2 \mathrm{H}_{2} \mathrm{O}$. 


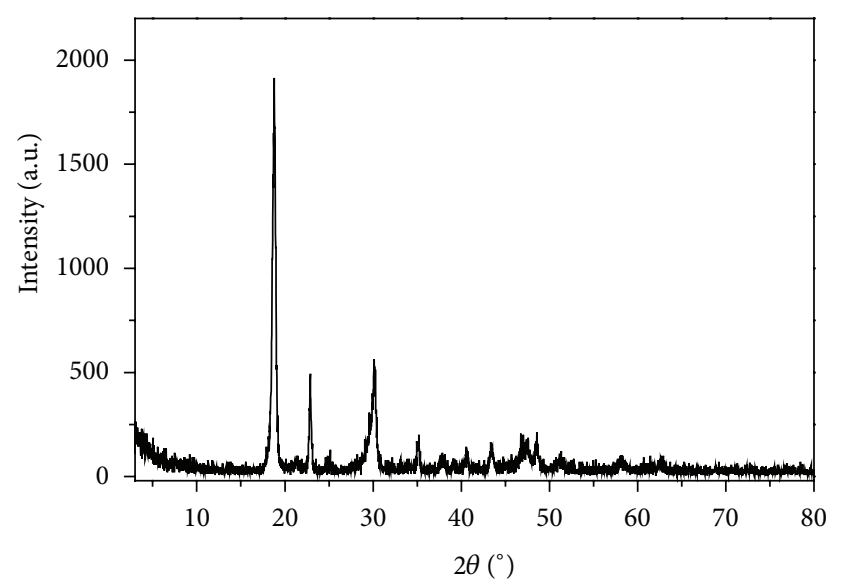

FIGURE 9: XRD pattern of the residue.

\section{Conclusion}

The complex $\left[\mathrm{Co}(\mathrm{pic})_{2}\left(\mathrm{H}_{2} \mathrm{O}\right)_{2}\right] \cdot 2 \mathrm{H}_{2} \mathrm{O}$ was synthesized with the reaction of cobalt acetate and 2-picolinic acid as the reactants. The composition and structure of the complex were characterized by EA, FTIR, single crystal X-ray diffraction, and TG-DSC. The crystal structure of the complex belongs to monoclinic system and space group $P 2(1) / n$, with cell parameters of $a=9.8468(7) \AA, b=5.2013(4) \AA, c=14.6041(15) \AA$, $\beta=111.745(6)^{\circ}, Z=2$, and $D_{c}=1.666 \mathrm{~g} \mathrm{~cm}^{-3}$. The cobalt ion is six-coordinated by two pyridyl $\mathrm{N}$ atoms and two carboxyl $\mathrm{O}$ atoms from two 2-picolinic anions and two $\mathrm{O}$ atoms from two $\mathrm{H}_{2} \mathrm{O}$ molecules, forming a distorted octahedral geometry. The thermal decomposition processes of the complex under nitrogen include dehydration and pyrolysis of the ligand, and the final residue is cobalt oxalate at about $450^{\circ} \mathrm{C}$.

\section{Additional Material}

Crystallographic data for the title complex $\left[\mathrm{Co}(\mathrm{pic})_{2}\left(\mathrm{H}_{2} \mathrm{O}\right)_{2}\right]$. $2 \mathrm{H}_{2} \mathrm{O}$ has been deposited with the Cambridge Crystallographic Data Centre. The deposition number is CCDC913361. The data can be obtained free of charge on application to the Director, CCDC, 12 Union Road, Cambridge, UK; fax: +44 1223366 033; e-mail: deposit@ccdc.ac.uk, or on the web http://www.ccdc.cam.ac.uk/pages/Home.aspx, or from the authors on request.

\section{Conflict of Interests}

The authors declare that there is no conflict of interests regarding the publication of this paper.

\section{Acknowledgments}

The authors gratefully acknowledge the financial support from the National Natural Science Foundation of China (no. 21201142) and the Scientific Research Funds of Sichuan Provincial Education Department of China (no. 10ZA016).
The authors are very grateful to State Key Laboratory Cultivation Base for Nonmetal Composite and Functional Materials and Engineering Research Center of Biomass Materials of Education Ministry for the testing.

\section{References}

[1] Y. W. Li, Y. Tao, and T. L. Hu, "Synthesis, structure, and photoluminescence of $\mathrm{Zn}(\mathrm{II})$ and $\mathrm{Cd}(\mathrm{II})$ coordination complexes constructed by structurally related 5, 6-substituted pyrazine-2, 3-dicarboxylate ligands," Solid State Sciences, vol. 14, no. 8, pp. 1117-1125, 2012.

[2] E. Colacio, M. A. P. María A. Palacios, A. R. Antonio RodríguezDíeguez et al., "3d-3d-4f chain complexes constructed using the dinuclear metallacyclic complex $\left[\mathrm{Ni}_{2}(\mathrm{mbpb})_{3}\right]^{2-}\left[\mathrm{H}_{2} \mathrm{mbpb}=1\right.$, 3-Bis(pyridine-2-carboxamide)benzene] as a ligand: synthesis, structures, and magnetic properties," Inorganic Chemistry, vol. 49, no. 4, pp. 1826-1833, 2010.

[3] G. Günay, O. Z. Yeşilel, M. S. Soylu, S. Keskin, and H. Dal, “Two novel $2 \mathrm{D}$ and $3 \mathrm{D}$ coordination polymers constructed from pyrazine-2,3-dicarboxylic acid and chloride bridged secondary building units," Synthetic Metals, vol. 161, no. 21-22, pp. 24712480, 2011.

[4] J. Cui, Y. Li, Z. Guo, and H. Zheng, "A porous metal-organic framework based on $\mathrm{Zn}_{6} \mathrm{O}_{2}$ clusters: chemical stability, gas adsorption properties and solvatochromic behavior," Chemical Communications, vol. 49, no. 6, pp. 555-557, 2013.

[5] S. M. Fang, E. C. Sañudo, M. Hu et al., "Hydrothermal syntheses, crystal structures, and magnetic properties of a series of unique three-dimensional lanthanide-organic coordination frameworks with a $\mathrm{N}$-protonated 2,6-dihydroxypyridine-4carboxylate tecton," Crystal Growth and Design, vol. 11, no. 3, pp. 811-819, 2011.

[6] Q. Yang, J. Zhao, B. Hu, X. Zhang, and X. Bu, "New manganese(II) azido coordination polymers with nicotinic/isonicotinic acids as coligands: synthesis, structure, and magnetic properties," Inorganic Chemistry, vol. 49, no. 8, pp. 3746-3751, 2010.

[7] X. Hu, Y. Zeng, Z. Chen et al., " $3 \mathrm{~d}-4 \mathrm{f}$ coordination polymers containing alternating EE/EO azido chain synthesized by synergistic coordination of lanthanide and transition metal ions," Crystal Growth and Design, vol. 9, no. 1, pp. 421-426, 2009.

[8] P. A. Tanner and C. Duan, "Luminescent lanthanide complexes: selection rules and design," Coordination Chemistry Reviews, vol. 254, no. 23-24, pp. 3026-3029, 2010.

[9] Y. G. Huang, F. L. Jiang, and M. C. Hong, "Magnetic lanthanidetransition-metal organic-inorganic hybrid materials: from discrete clusters to extended frameworks," Coordination Chemistry Reviews, vol. 253, no. 23-24, pp. 2814-2834, 2009.

[10] G. H. Cui, C. H. He, C. H. Jiao, J. C. Geng, and V. A. Blatov, "Two metal-organic frameworks with unique high-connected binodal network topologies: synthesis, structures, and catalytic properties," CrystEngComm, vol. 14, no. 12, pp. 4210-4216, 2012.

[11] G. Novitski, A. Borta, S. Shova, O. N. Kazheva, M. Gdaniec, and Y. A. Simonov, "Synthesis and structure of Co(III) complexes with 2-pyridinecarboxylic acid," Russian Journal of Inorganic Chemistry, vol. 53, no. 2, pp. 202-208, 2008.

[12] B. M. Kukovec, Z. Popović, G. Pavlović, and M. Rajić Linarić, "Synthesis and structure of cobalt(II) complexes with hydroxyl derivatives of pyridinecarboxylic acids: conformation analysis 
of ligands in the solid state," Journal of Molecular Structure, vol. 882, no. 1-3, pp. 47-55, 2008.

[13] J. H. Luo, M. C. Hong, Q. Shi et al., "Synthesis, structure and magnetic properties of a quasi-two-dimensional compound $\left[\mathrm{Cu}\left(\mathrm{C}_{5} \mathrm{H}_{4} \mathrm{NCOO}\right)_{2}\right] \cdot 2 \mathrm{H}_{2} \mathrm{O}$," Transition Metal Chemistry, vol. 27, no. 3, pp. 311-315, 2002.

[14] Z. Vargová, V. Zeleòák, I. Císaøová, and K. Györyová, “Correlation of thermal and spectral properties of zinc(II) complexes of pyridinecarboxylic acids with their crystal structures," Thermochimica Acta, vol. 423, no. 1-2, pp. 149-157, 2004.

[15] G. Q. Zhong, W. W. Zhong, R. R. Jia, and Y. Q. Jia, "Solidstate synthesis, characterization and biological activity of the bioinorganic complex of aspartic acid and arsenic triiodide," Journal of Chemistry, vol. 2013, Article ID 217947, 5 pages, 2013.

[16] G. Q. Zhong, R. R. Jia, and Y. Q. Jia, "Solid-solid reaction preparation for nanoparticles of bioinorganic complex of bismuth and serine at room temperature," Advanced Materials Research, vol. 549, pp. 292-296, 2012.

[17] C. Y. Min, X. F. Yang, R. X. Zhang, F. Yao, and W. M. Ouyang, "Greener solid state synthesis of a ternary lanthanum complex at room temperature," Journal of Coordination Chemistry, vol. 64, no. 9, pp. 1617-1625, 2011.

[18] M. Méret and S. Bienz, "Efficient and flexible solid-phase synthesis of $\mathrm{N}$-hydroxypolyamine derivatives," European Journal of Organic Chemistry, no. 33, pp. 5518-5525, 2008.

[19] B. M. Kukovec, I. Kodrin, Z. Mihalić, K. Furić, and Z. Popović, "Cis-trans isomerism in cobalt(II) complexes with 3hydroxypicolinic acid. Structural, DFT and thermal studies," Inorganica Chimica Acta, vol. 363, no. 8, pp. 1887-1896, 2010.

[20] T. W. Failes, C. Cullinane, C. I. Diakos, N. Yamamoto, J. G. Lyons, and T. W. Hambley, "Studies of a cobalt(III) complex of the MMP inhibitor marimastat: a potential hypoxia-activated prodrug," Chemistry, vol. 13, no. 10, pp. 2974-2982, 2007.

[21] H. López-Sandoval, M. E. Londoño-Lemos, R. Garza-Velasco et al., "Synthesis, structure and biological activities of cobalt(II) and zinc(II) coordination compounds with 2-benzimidazole derivatives," Journal of Inorganic Biochemistry, vol. 102, no. 5-6, pp. 1267-1276, 2008.

[22] F. Dimiza, A. N. Papadopoulos, V. Tangoulis et al., "Biological evaluation of non-steroidal anti-inflammatory drugs-cobalt(ii) complexes," Dalton Transactions, vol. 39, no. 19, pp. 4517-4528, 2010.

[23] O. Z. Yeşilel, A. Mutlu, C. Darcan, and O. Büyükgüngör, "Syntheses, structural characterization and antimicrobial activities of novel cobalt-pyrazine-2,3-dicarboxylate complexes with $\mathrm{N}$ donor ligands," Journal of Molecular Structure, vol. 964, no. 1-3, pp. 39-46, 2010.

[24] P. Segl’a, J. Miklovič, D. Mikloš et al., "Crystal structure, spectroscopic and magnetic properties, and antimicrobial activities of cobalt(II) 2-methylthionicotinate complexes with $\mathrm{N}$ heterocyclic ligands," Transition Metal Chemistry, vol. 33, no. 8, pp. 967-974, 2008.

[25] D. Georgiou and V. G. Papangelakis, "Behaviour of cobalt during sulphuric acid pressure leaching of a limonitic laterite," Hydrometallurgy, vol. 100, no. 1-2, pp. 35-40, 2009.

[26] G. M. Sheldrick, SHELXS 97, Program for the Solution of Crystal Structure, University of Göttingen, Göttingen, Germany, 1997.

[27] G. M. Sheldrick, SHELXS 97, Program for the Refinement of Crystal Structure, University of Göttingen, Göttingen, Germany, 1997.
[28] C. Janiak, "A critical account on $\pi-\pi$ stacking in metal complexes with aromatic nitrogen-containing ligands," Journal of the Chemical Society, Dalton Transactions, no. 21, pp. 3885-3896, 2000.

[29] M. A. Neelakantan, F. Rusalraj, J. Dharmaraja, S. Johnsonraja, T. Jeyakumar, and M. Sankaranarayana Pillai, "Spectral characterization, cyclic voltammetry, morphology, biological activities and DNA cleaving studies of amino acid Schiff base metal(II) complexes," Spectrochimica Acta A, vol. 71, no. 4, pp. 1599-1609, 2008.

[30] G. Zhong, J. Shen, Q. Jiang, and K. Yu, "Synthesis and structural determination of a novel heterometallic complex $\left[\mathrm{Sb}_{2}(\text { edta })_{2}\right.$ $\left.\mu_{4}-\mathrm{Co}\left(\mathrm{H}_{2} \mathrm{O}\right)_{2}\right] \cdot 5.15 \mathrm{H}_{2} \mathrm{O}$," Chinese Journal of Chemistry, vol. 29, no. 12, pp. 2650-2654, 2011.

[31] J. Wang, X. Zhang, Z. Liu, and W. Jia, "Synthesis and structural determination of binuclear nine-coordinate $\left(\mathrm{NH}_{4}\right)_{4}$ $\left[\mathrm{Yb}_{2}(\mathrm{dtpa})_{2}\right] \cdot 9 \mathrm{H}_{2} \mathrm{O}$," Journal of Molecular Structure, vol. 613, no. 1-3, pp. 189-193, 2002.

[32] K. Nakamoto, Infrared and Raman Spectra of Inorganic and Coordination Compounds, John Wiley \& Sons, New York, NY, USA, 4th edition, 1986.

[33] G. Q. Zhong, J. Shen, Q. Y. Jiang, Y. Q. Jia, M. J. Chen, and Z. P. Zhang, "Synthesis, characterization and thermal decomposition of $\mathrm{Sb}^{I I I}-\mathrm{M}-\mathrm{Sb}^{I I I}$ type trinuclear complexes of ethylenediamine$N, N, N$, $N^{\prime}$-tetraacetate (M:Co $\left.\left({ }^{I I}\right), \operatorname{La}\left({ }^{I I I}\right), \operatorname{Nd}\left({ }^{I I I}\right), \operatorname{Dy}\left({ }^{I I I}\right)\right)$," Journal of Thermal Analysis and Calorimetry, vol. 92, no. 2, pp. 607-616, 2008.

[34] J. R. Allan, W. C. Geddes, C. S. Hindle, and A. E. Orr, “Thermal analysis studies on pyridine carboxylic acid complexes of zinc(II)," Thermochimica Acta C, vol. 153, pp. 249-256, 1989. 

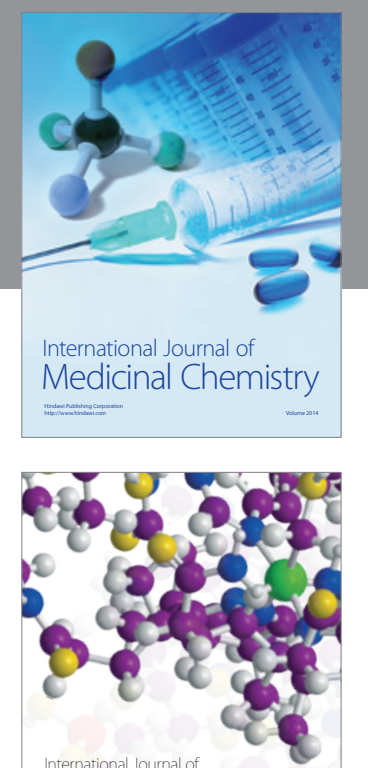

\section{Carbohydrate} Chemistry

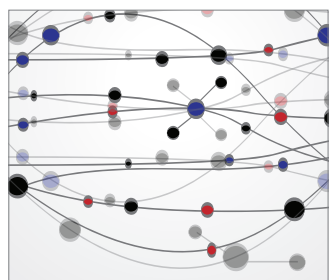

The Scientific World Journal
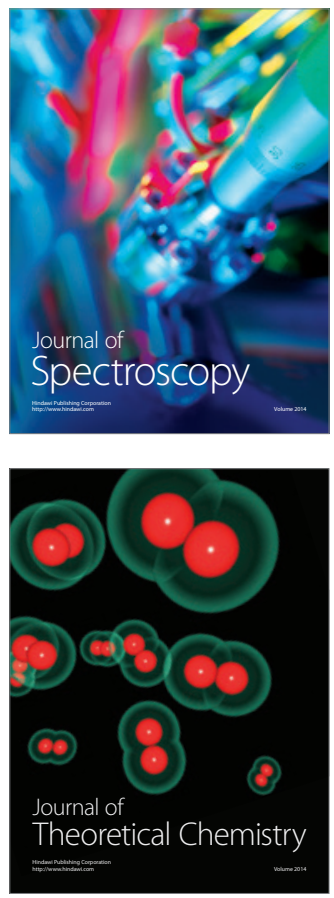
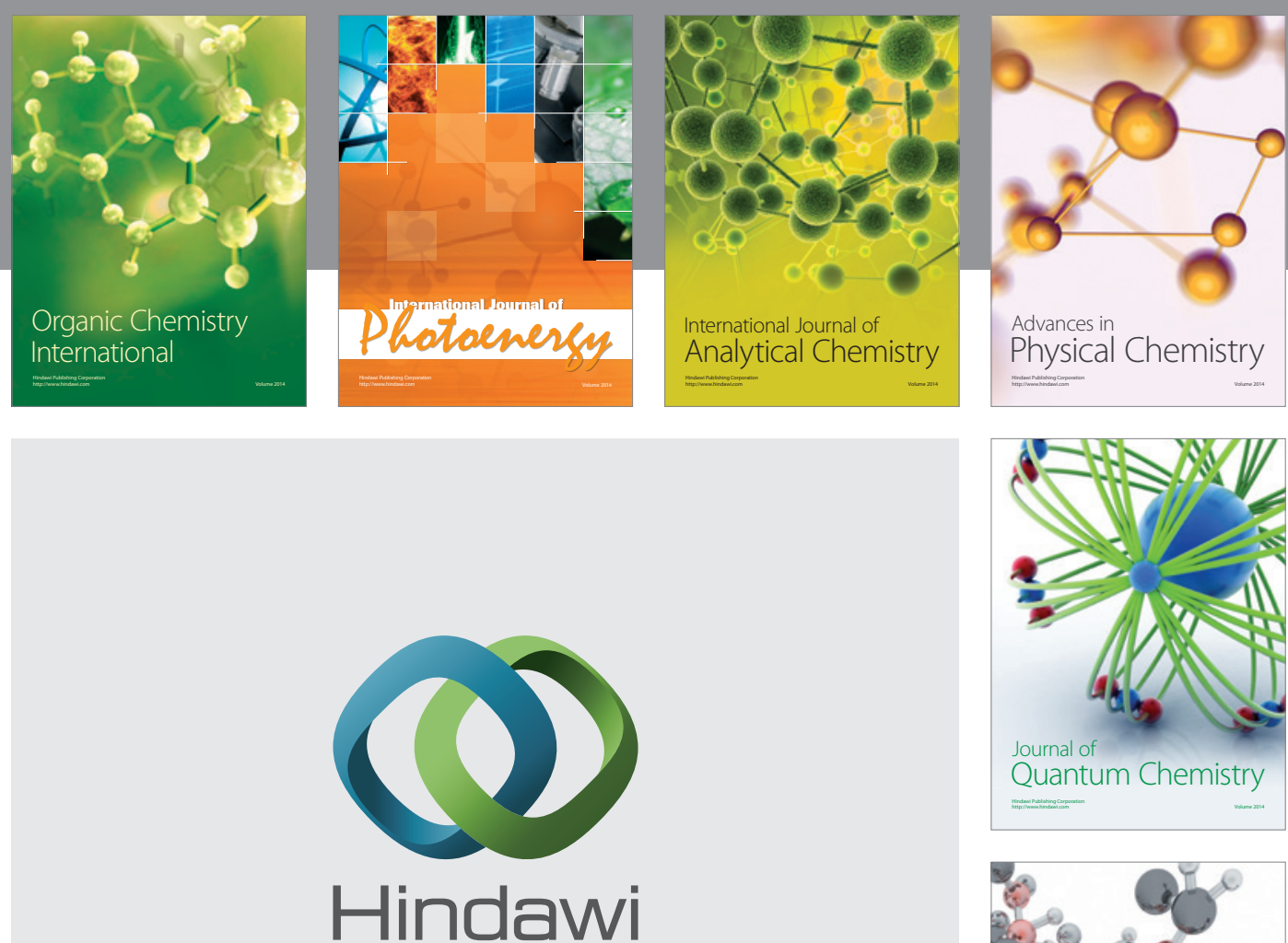

Submit your manuscripts at

http://www.hindawi.com

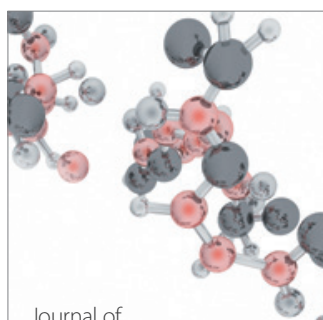

Analytical Methods

in Chemistry

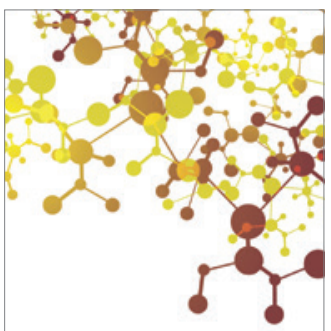

Journal of

Applied Chemistry

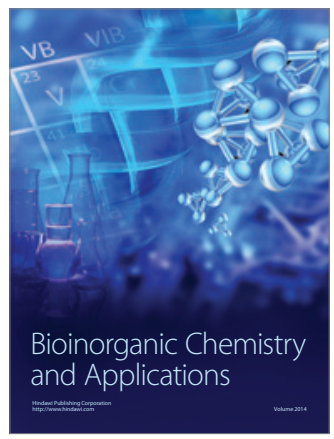

Inorganic Chemistry
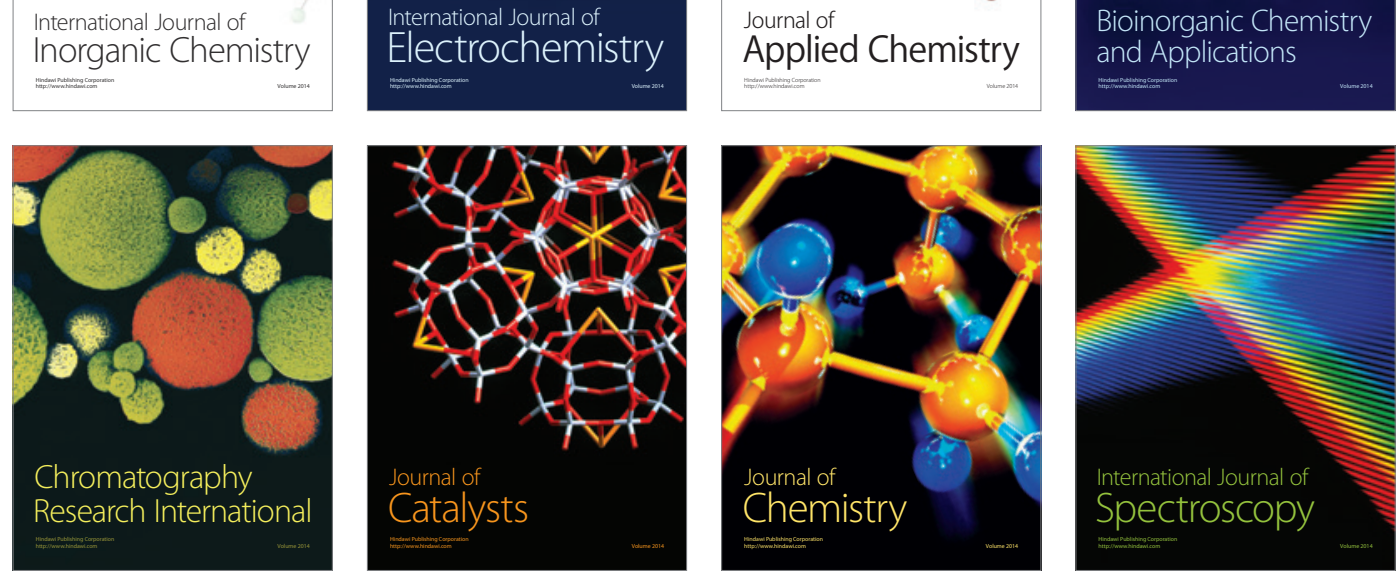